\title{
The Use of Pictorial Analogy to Increase Students' Achievement and Its Retention of Physics Lessons of Direct Current
}

\author{
Tomo Djudin ${ }^{1, a, *}$ and Selvaraj Grapragasem ${ }^{2, b}$ \\ ${ }^{1}$ Physics Education Department of Education and Teacher Training Faculty, Universitas Tanjungpura \\ Jl. Prof. Dr. H. Hadari Nawawi, Komp. Fakultas MIPA, Pontianak 78124, Indonesia \\ ${ }^{2}$ Department of Educational Studies, Institut Pendidikan Guru Malaysia \\ Sarawak Campus, Miri Sarawak, Kuching 98009, Malaysia \\ e-mail: ${ }^{a}$ tomo.djudin@yahoo.com and ${ }^{\mathrm{b}}$ gselva62@gmail.com \\ * Corresonding Author
}

\begin{abstract}
Analogy is considered a helpful way to help students visualize abstract concepts and assimilate new knowledge to an existing structure of cognitive. This study examines the effectiveness of the teaching with pictorial analogy models on students' achievement and its retention of Direct Current lesson. A quasiexperimental method with one group pretest and (immediate and delayed) posttest design was employed in this study. The subjects consisted of 35 twelfth-grade students of public senior school in Pontianak City enrolled in the first semester of academic year 2017/2018; they were determined by using intact group random sampling technique. The student participants received instructions of the three pictorial analogy models. A parallel pretest-posttest of achievement test consisted of 10 items of factual knowledge, 10 items of conceptual knowledge, and 3 items of procedural knowledge. The operationalization of the pictorial analogies in this study referred to Glynn's syntaxes. Data analysis found that: (1) the increasing of factual knowledge is $30.2 \%$ in immediate posttest and $21.6 \%$ in delayed posttest; (2)the students have promoted a significant conceptual change $\left(\chi^{2}=54.28, p<0.05\right)$; and (3) there is a significant difference between the immediate posttest and pretest in terms of procedural knowledge $(t=4.02 ; p<0.05)$ with the ES index is 4.78. It is concluded that the use of pictorial analogy models is effective (in high category) to increase students' achievement of Direct Current lesson and the emergence of their retention is significant partially and simultaneously. In using pictorial analogies, teachers are encouraged to consider many similar features with the target concepts.
\end{abstract}

Keywords: pictorial analogies, retention, factual knowledge, conceptual knowledge, procedural knowledge

\section{Penggunaan Pictorial Analogy untuk Meningkatkan Capaian dan Kemampuan Retensi Siswa pada Pembelajaran Fisika Materi Arus Searah}

\begin{abstract}
Abstrak
Analogi dianggap sebagai cara yang dapat membantu siswa memvisualisasikan konsep abstrak dan mengasimilasikan pengetahuan baru ke struktur kognitif yang telah ada. Penelitian ini dilakukan untuk menguji tingkat efektivitas model pembelajaran analogi bergambar terhadap hasil belajar dan retensinya
\end{abstract}

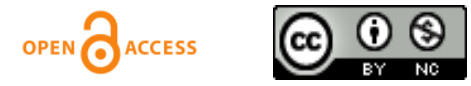


pada materi arus listrik searah. Penelitian ini menerapkan metode quasy-experimental dengan rancangan one group pretest and (immediate and delayed) posttest. Sebanyak 35 siswa kelas XII-1 SMAN 1 Pontianak pada semester pertama tahun ajaran 2017/2018 diambil sebagai sampel menggunakan teknik intact group random sampling. Subyek penelitian diberikan perlakuan sebanyak 3 kali pembelajaran model analogi bergambar. Tes awal dan tes akhir adalah ekuivalen dan terdiri dari 10 soal pengetahuan faktual, 10 soal pengetahuan konseptual, dan 3 soal pengetahuan prosedural. Operasionalisasi langkah-langkah pembelajaran model analogi bergambar dalam penelitian ini mengacu pada sintaks dari Glynn. Analisis data menemukan bahwa: (1) Peningkatan pengetahuan faktual sebesar 30,2\% pada tes akhir dan 21,6\% pada tes tunda; (2) Siswa mengalami perubahan konseptual setelah perlakuan $\left(\chi^{2}=54,28, p<0,05\right)$; dan (3) Terdapat perbedaan pengetahuan prosedural pada tes akhir dan tes awal $(t=4,02 ; p<0,05)$ dengan nilai Effect Size $(E S)=4,78$. Penelitian ini menyimpulkan bahwa penggunaan model analogi bergambar efektif (dengan kategori tinggi) untuk meningkatkan hasil beljar siswa pada materi listrik statis dan retensinya terjadi baik secara parsial (per dimensi pengetahuan) maupun keseluruhan. Dalam menggunakan analogi bergambar, guru perlu mempertimbangkan beberapa ciri yang sama dari konsep analog dengan konsep target.

Kata Kunci: analogi bergambar, retensi, pengetahuan faktual, pengetahuan konseptual, pengetahuan prosedural

PACS: 01.40.gb, 01.40.ek

(C) 2019 Jurnal Penelitian Fisika dan Aplikasinya (JPFA). This work is licensed under CC BY-NC 4.0

Article History: Received: November 27, 2018

Accepted: December 6, 2019
Approved with minor revision: November 21, 2019

Published: December 31, 2019

How to cite: Djudin T and Grapragasem S. The Use of Pictorial Analogy to Increase Students' Achievement and Its Retention of Physics Lessons of Direct Current. Jurnal Penelitian Fisika dan Aplikasinya (JPFA). 2019; 9(2): 140151. DOI: https://doi.org/10.26740/jpfa.v9n2.p140-151.

\section{INTRODUCTION}

One of topics of Physics Education in senior high school is direct current. Direct current is considered as one of the fundamental topics as it abounds and involves many professions, and it is related to daily human activities [1]. Unfortunately, gaining understanding on electricity seems to be very challenging and difficult for students in various education levels. A number of previous studies have been conducted in this matter [2-7] indicating that students are believed to have difficulties and misunderstandings after systematic instructions. Cibik and Yalclm, for instance, indicated that the most frequently encountered findings concerning with students' misunderstandings of direct current in secondary education are namely as follows: (1) batteries are constant current sources; (2) current is consumed by circuit components; (3) current comes out from the $(+)$ pole of the battery and enters to the bulb where it is consumed to light the bulb which is not affected by the second wire connected between the (-) pole and itself; (4) current comes out from the both poles of the battery and clashes in the bulb to light it; (5) current is divided equally in each line of the parallel circuits; and (6) a change before the bulb affects the brightness of the bulb in circuit connected in series, but the same bulb is not affected by change in anywhere of the circuit after the bulb [8].

It is not surprising that students have difficulties to understand the electric current because electrons are far from students' experiences or observations, and it is 
considered as very abstract [9]. Cinyere and Madu confirmed that in order to help students visualize abstract and unobservable phenomenon, teachers may use analogies. The role of analogy in learning has been extensively researched in Science Education [10]. Some previous researchers have found that the use of analogy in Physics learning and teaching are effective to: (1) promote students' conceptual change [11-13]; (2) increase students' understanding and achievement [14-15]; and (3) improve students' motivation in learning [16,17]; (4) develop students' attitudes toward Physics lesson [3,8]; and (5) help students construct new knowledge by linking it with knowledge structure they already have and guide students from their pre-instructional conception towards science concepts $[18,19]$. Therefore, for forthcoming study, it is fascinating to investigate the role of analogies with interpretations of students' achievement from various dimension of knowledge and perspectives.

Currently, Indonesia has been implementing the Curriculum 2013 (K13) under the coordination of Ministry of Education and Culture. It is acknowledged that after having received teaching-learning processes of Physics, senior high school students should acquire four dimensions of basic knowledge in standard competencies, namely factual knowledge, conceptual knowledge, procedural knowledge, and metacognitive knowledge [20]. Simply stated, factual knowledge seeks to recall information from textbook or various sources. Conceptual knowledge encourages students to describe factual information and become aware of the "relationships between the elements of a larger structure". Procedural knowledge assesses students' ability to choose from wellestablished methods and select the most appropriate algorithm, technique, or criteria based on the particular situation. Finally, metacognitive knowledge encourages students to reflect on their learning experiences and identify possible areas of improvement [21].

Students' lack of understandings in the learning of direct current of Physics lesson in senior high school in terms of conceptual knowledge has been studied in the several previous studies [22-24]. However, there are only few previous studies that investigate specific instructional practices of analogies for increasing simultaneously students' factual knowledge, promoting students' conceptual changes, and improving students' ability to solve physics problems, and its retention. In addition, to what the extent of effectiveness does the teaching with analogy in arising students' understanding of direct current circuit in secondary school, even with decades of research, is far from the studies.

In the context of this study, most of twelfth-grade students of one public school in Pontianak city showed negative symptoms while learning Physics. They lack of independence and confidence about the subject matters they have learned, having a lot of misconceptions but less interests in the lesson, and quickly forgetting the essential concepts they have learned. The success rate in academic achievement of the students for Direct Current topic in Physics lesson has not reached the minimum standard of passing grade i.e. $75 \%$ per class. The percentage of classes with passing grade for more than $75 \%$ is still quite low. The students also perceived that Direct Current topic is the most difficult topic. This issue becomes one of the focuses of the teachers to overcome. Teachers asserted that sometimes using the real laboratories and has never used the (pictorial) analogies in the learning of direct current.

This study is intended to examine to what extent of the effectiveness does the teaching with analogy model in increasing students' understanding of Direct Current circuits of Physics lesson and its retention at 
senior high school in terms of factual, conceptual, and procedural knowledge partially and simultaneously.

\section{RESEARCH METHOD}

A quasi-experimental method with one group pretest and (immediate and delayed) posttest was used as the research design in this study [25]. The target population was the twelfth-grade students (age between 16-18 years old) of public senior high school SMAN 1 Pontianak, located in urban area $(N=324)$ who enrolled in the first semester of academic year 2017/2018. The sample consisted of 35 students of Class XII-1 which was drawn by using intact group random sampling technique. The dependent variable was the students' factual knowledge, conceptual knowledge, procedural knowledge, and understanding (score) of Direct Current Circuits topic of Physics lesson of the senior high school level. The independent variable was the pictorial analogies designed to teach the Direct Current topic.

In this study, the instructional sequences of the teaching activities by using pictorial analogy model referred to Glynn's syntaxes which consisted of: (1) introducing the target concepts to the students which were depicted in a pictorial diagram on students' worksheet; (2) reminding the students of what they know upon the analog concept; (3) identifying relevant features of target concepts and analog concept; (3) mapping similarities between the target concepts and analog concept in which both processes and electrons moving; (4) indicating where the analogy break down is different one; and (5) drawing conclusions about the target concepts [12]. The Glynn's syntaxes are considered applicable to the wide range of devices referred as analogies in educational literature [26,27]. The student participants in this study received three instructions, namely: (1) Analogy of fluid flow in a pipe for Ohm's Law [3], (2) Analogy of a vehicle traveling on a highway for series circuits [14], and (3) Analogy of fluid flowing in a pipe for parallel circuits $[9,14]$. The operationalization of the pictorial analogies in this study can be seen in Appendix 1 (see Supplementary File).

A parallel pretest-posttest design of achievement test consisted of 10 items of factual knowledge (with KR-21 coefficient is 0.62 ), 10 items of conceptual knowledge (with KR-21 coefficient is 0.58 ), and 3 items of procedural knowledge (with Cronbach Alpha coefficient of 0.71). In the conceptual knowledge test, students were assigned to give an answer to each question and the reason of his/her answer to the first questions being asked.

No feedback was given to the students after administering the tests, but the scores were reserved for use after the posttests. Students were asked not to discuss their responses or solutions after pretest and immediate posttest for they would have an opportunity to discuss their performances when the delayed posttest was administered after two weeks of the immediate posttest. Within the period of two weeks (three times instructions with $2 \times 45$ minutes each), it was used to carry out the treatments to implement the proposed pictorial analogies. Students were administered the pretest and posttests in a 50-minute period. Only students who completed the tests were analyzed in this study.

In order to describe the profiles of students' understanding and conceptions on direct current circuits topic before and after the treatment, the (nominal) data were analyzed by using simple percentage calculations. The significance of students' conceptual change was examined by using a non-parametric McNemar's test and the difference of two proportions by using $\chi^{2}$ [25]. The pair-sample t-test was used in order to compare the pretest and posttest scores. To what extent of the effectiveness does the 
Jurnal Penelitian Fisika dan Aplikasinya (JPFA), 2019; 9(2): 140-151

teaching with analogy on promoting students' conceptual change, increasing students' understanding, and its retention, the score (interval data) was assessed by using the Effect Size [28], namely $E S$, that is, the difference between the means of posttest and pretest, $M_{1}-M_{2}$, and divided by standard deviation of either test.

\section{III.RESULTS AND DISCUSSION Students' Achievement of Factual Knowledge}

The factual knowledge test distributed to the students consisted of 10 items and the entire score was 20. The profiles (percentages) of the correct answers of the factual knowledge is presented in Table 1, and the average score of students' achievement of the factual knowledge is shown in Table 4.

Table 1. Profiles (Percentages) of Students' Correct Answers of Factual Knowledge

\begin{tabular}{clccc}
\hline Items & Indicators of factual knowledge & Pretest & $\begin{array}{c}\text { Immediate } \\
\text { Posttest }\end{array}$ & $\begin{array}{c}\text { Delayed } \\
\text { Posttest }\end{array}$ \\
\hline 1 & To name the moving electric charge & $71.4 \%$ & $85.7 \%$ & $80.0 \%$ \\
2 & To define "one ampere" & $14.3 \%$ & $67.1 \%$ & $61.4 \%$ \\
3 & To describe electric current & $80.0 \%$ & $91.4 \%$ & $85.7 \%$ \\
4 & To recognize closed and opened circuits & $71,4 \%$ & $91.7 \%$ & $77.1 \%$ \\
5 & To recognize the symbols of an electric potential & $57.1 \%$ & $85.7 \%$ & $74.3 \%$ \\
6 & To recognize the symbols of a resistor & $77.1 \%$ & $97.1 \%$ & $88.6 \%$ \\
7 & To describe the nature of conductor & $28.6 \%$ & $80.0 \%$ & $65.7 \%$ \\
8 & To state the Kirchoff Law & $74.3 \%$ & $97.1 \%$ & $91.4 \%$ \\
9 & To state the Ohm Law & $34.3 \%$ & $74.3 \%$ & $62.9 \%$ \\
\hline & To state the name of the electrical devices & $45.7 \%$ & $85.7 \%$ & $82.9 \%$ \\
\hline
\end{tabular}

As seen in Table 1, the increasing percentage of factual knowledge is $30.2 \%$ for the immediate posttest and $21.6 \%$ for delayed posttest. These results indicate that the success percentage of students' correct answers of the factual knowledge is considerably increased after the treatment given to the students. By comparing the percentage means of the immediate and delayed posttests, it is found that $\chi^{2}=0.856, p>0.05$, meaning the retention occurs significantly.

\section{Students' Achievement of Conceptual Knowledge and Conceptual Changes}

The conceptual knowledge test distributed to the students consisted of 10 items. The score for one correct answer supported with one reason which is consistent with scientific conception is 4 , while the score for one correct answer is 2 . The profiles (mean of percentages) students' misconceptions about direct current are shown in Table 2a, and the result of McNemar-test on the conceptual change is shown in Table 2b. According to the results in Table $2 \mathrm{a}$, not all of conceptual misunderstandings (misconceptions) are eliminated completely. Nevertheless, the conceptual misunderstandings reduce significantly after the treatment of $73.5 \%$ during the immediate posttest. The difference of means of percentage of the conceptual knowledge between the immediate and delayed posttests is $18.6 \%$, and this is not considered significant $\left(\chi^{2}=1.682, p>0.05\right)$. It means that there is a significant retention of the conceptual knowledge. 
Jurnal Penelitian Fisika dan Aplikasinya (JPFA), 2019; 9(2): 140-151

In Table $2 \mathrm{~b}$, by using McNemar-test, to after having received the instructional examine the students' conceptual change after teaching by employing pictorial analogy, the treatment, it is shown that $\chi_{o}^{2}(54.28)$ bigger than $\chi_{\text {table }}^{2}(3.84)$. It is concluded that students have promoted significant conceptual changes for the direct current circuits topic.

Table 2a. Profiles (Percentages) of Dominant Students' Misconceptions

\begin{tabular}{|c|c|c|c|c|}
\hline Items & Dominant students' misconceptions & Pretest & $\begin{array}{c}\text { Immediate } \\
\text { Posttest }\end{array}$ & $\begin{array}{l}\text { Delayed } \\
\text { Posttest }\end{array}$ \\
\hline 1 & Electric current can also move in the opened circuits & $60.0 \%$ & $11.4 \%$ & $28.6 \%$ \\
\hline 2 & Two points in the series circuits have different current & $45.7 \%$ & $2.5 \%$ & $18.6 \%$ \\
\hline 3 & $\begin{array}{l}\text { Resistance rate of the series circuits is lower than the } \\
\text { parallel circuits }\end{array}$ & $74.3 \%$ & $2.6 \%$ & $37.1 \%$ \\
\hline 4 & $\begin{array}{l}\text { Resistance of the series circuits is similar the parallel } \\
\text { circuits }\end{array}$ & $71.4 \%$ & $14.3 \%$ & $42.9 \%$ \\
\hline 5 & $\begin{array}{l}\text { The brightness of a bulb produced by two batteries is similar } \\
\text { to one battery }\end{array}$ & $65.7 \%$ & $25.7 \%$ & $32.9 \%$ \\
\hline 6 & $\begin{array}{l}\text { If resistance is increased, the brightness of a bulb is remains } \\
\text { constant }\end{array}$ & $74.3 \%$ & $20.0 \%$ & $40.0 \%$ \\
\hline 7 & $\begin{array}{l}\text { The increasing of electric current will cause the decreasing } \\
\text { of the potential difference }\end{array}$ & $71.4 \%$ & $14.3 \%$ & $25.7 \%$ \\
\hline 8 & $\begin{array}{l}\text { While the closed switch is opened, the resistance rate in } \\
\text { series circuits is similar or increasing }\end{array}$ & $65.7 \%$ & $20.0 \%$ & $42.9 \%$ \\
\hline 9 & $\begin{array}{l}\text { The brightness of some bulbs in the series circuits and } \\
\text { parallel circuits is similar }\end{array}$ & $65.7 \%$ & $11.4 \%$ & $25.7 \%$ \\
\hline 10 & $\begin{array}{l}\text { The increasing or decreasing of potential difference does } \\
\text { not affect the brightness of the bulb }\end{array}$ & $71.4 \%$ & $25.7 \%$ & $40.0 \%$ \\
\hline & Average percentages of misconception & $88.3 \%$ & $14.8 \%$ & $33.4 \%$ \\
\hline & Reduction & \multicolumn{2}{|c|}{$73.5 \%$} & $18.6 \%$ \\
\hline
\end{tabular}

Table 2b. Cells of McNemar-test

\begin{tabular}{ccccc}
\hline & & \multicolumn{2}{c}{ Immediate Posttest } & \multirow{2}{*}{$\chi^{2}$} \\
\cline { 2 - 3 } Pretest & - & 157 & 44 & \\
& & & & 54.28 \\
& + & 99 & 50 & \\
\hline
\end{tabular}

\begin{abstract}
Students' Achievement of Procedural 10 respectively, while number three is 20 . The Knowledge entire score for this domain is 40 . The mean

The procedural knowledge test scores of the procedural knowledge test distributed to the students consisted of 3 items. results are presented in Table 3.
\end{abstract} The score of number one and number two is 
Table 3. Mean Scores of Procedural Knowledge

\begin{tabular}{|c|c|c|c|c|}
\hline Items & Indicators & Pretest & $\begin{array}{c}\text { Immediate } \\
\text { Posttest }\end{array}$ & $\begin{array}{l}\text { Delayed } \\
\text { Posttest }\end{array}$ \\
\hline 1 & Calculate the quantity of electric current by using Kirchoff Law & 250 & 320 & 290 \\
\hline 2 & Calculate the potential differences of the bulbs in series circuits & 380 & 400 & 315 \\
\hline \multirow[t]{5}{*}{3} & Calculate the quantity of electric currents and potential & 50 & 255 & 220 \\
\hline & differences of the bulbs in parallel circuits & & & \\
\hline & $N$ & 35 & 35 & 35 \\
\hline & Mean & 19.43 & 27.86 & 23.57 \\
\hline & $S D$ & 3.92 & 3.19 & 3.41 \\
\hline
\end{tabular}

From Table 3, by comparing the means of procedural knowledge between the immediate posttest and pretest, it indicates significant change due to the treatment $(t=4.02 ; p<0.05)$. In addition, as there is no significant statistical difference between immediate posttest and delayed posttest $(t=1.56 ; p>0.05)$, this result indicates that there is a significant retention in terms of procedural knowledge of the students.

\section{Testing for Effect Size (ES) and Its Retention}

To calculate Effect Size $(E S)$ and test the emergence of retention, the total achievement scores were compared by using pair-sample $t$-test, and the result is shown in Table 4.

Table 4. Pair Sample t-test Results for Testing ES and Its Retention

\begin{tabular}{ccccccc}
\hline Statistic & Pretest & $\begin{array}{c}\text { Immediate } \\
\text { Posttest }\end{array}$ & $\begin{array}{c}\text { Delayed } \\
\text { Posttest }\end{array}$ & Retention \\
\hline \multirow{2}{*}{ Total } & $\mathrm{N}$ & 35 & 35 & 35 & $t=1.27$ & Yes \\
achievement score & Mean & 40.67 & 65.05 & 60.81 & $(p>0.05)$ & \\
\hline
\end{tabular}

Based on the data in Table 4, by using $t$ test, it is concluded that there is a significant statistical difference between pretest and immediate posttest of the total score $(t=7.49$; $p<0.05$ ), and the effectiveness of the teaching by employing pictorial analogy in the Physics lesson is in high category $(E S=4.78)$. In terms of immediate posttest and delayed posttest, however, there is no significant difference $(t=1.27 ; p>0.05)$ which indicates that its retention occurred during the treatment is significant. The finding of this study showed that not all of conceptual misunderstandings were eliminated completely after the instruction by using pictorial analogy given. Nevertheless, the reduction of percentages of the students' conceptual misunderstandings are reduced significantly and the students has promoted the conceptual changes. In addition, there is high retention of the students' achievement in the domain of conceptual knowledge. This finding is compliance with other study carried out by Ugur et al that concluded that teaching with analogy has significant positive effect on the elimination of misconception and achievement despite it has almost no effect on the attitudes of the students of toward Physics lesson [3].

The result is also relevant to the findings of some previous studies arguing that from the teaching perspective, the use of analogies is 
believed to enhance the conceptual change of learning science [16,29]. Actually, the scientific analogies may be utilized for more than one function for particular purposes. According to Chiu and Lin, scientific analogies have at least four distinguishable uses, namely discovery, development, evaluation, and exposition [15]. Of the common uses, the most exciting is discovery, in which the analogy may contribute to the formation of new hypothesis. Once one hypothesis has been formed, for instance, the analogy would facilitate further theoretical or experimental development. Analogy may also serve to form arguments either for or against one stance upon the hypothesis, and then the analogy may also be contributive to convey new ideas to other people.

Hynd et al stated that analogies are considered as the way of assimilating new knowledge to an existing structure and, therefore, is not a conceptual change [30]. If the analogies are appropriate, they may promote concept learning because they encourage students to build links between past familiar knowledge and experiences and new contexts of the problems. Because students have difficulty in identifying the relationship between target and analog, they are like to miss the real point of the analogy, and this is an excellent reason for teachers to use a systematic approach when teaching with analogies [23].

Glynn asserted that when using an analogy in the teaching of science, teachers should select an appropriate student's world analog to assist themselves in explaining the science concept [11]. The analog and target share attributes that allow a relationship to be identified, and it contribute to the concept being taught; however, there are certain features of the analogy that are not linear with the target. The use of analogies in the teaching of science does not always produce the intended effects, especially when the students take the analogy too far from the context and are unable to relate it with the content being learned. Some students only remember the analogy and not the content under study, while others focus on extraneous aspects of the analogy and draw conclusions about the target concept.

Although analogies could be used to promote the conceptual change, but many of students' conceptual misunderstandings are heavily resistant to change [31]. Some previous studies concluded that most students are unable to employ analogical reasoning to solve similar problems regarding different phenomena, and learners are not able to "see" the analogy [11]. The pictorial analogies are believed to aid the student's learning by providing visualization of abstract concepts, by helping to compare similarities of the students' real world with the new concepts and by increasing students' motivation [32]. The water analogy is also frequently used in this study, but there are some problems associated with the complete understanding of the target itself by a large number of students [23,33].

Erökten and Gökharman found the similar result in this study who concluded that using analogy method in unit "the Structure and Properties of Matter" was determined to increase the students' academic achievements [34]. This study also concluded that there was no significant statistical difference between immediate posttest and delayed posttest. The results indicated that its retention occurred significantly. It has been suggested that retention is an institutional-level measure of success, and that persistence is an individual or student-level measure of success [36]. However, this differentiation of terms has not been widely accepted. According to a sample of definitions that may be found in the research literature, retention refers to successful completion of students' academic goals of degree attainment. Engaging in a 
quality of student learning (retention) improvement process should provide an approach to organizing a systematic effort, while at the same time enhancing overall effectiveness and student success [35].

During the treatments in this study, the majority of students claimed that using analogies in lessons was useful, enjoyable, interesting, and so much fun because they perceived the use of analogies helped them to understand visualization concept. This study used a pictorial analogy in the learning of direct electric circuits for the first time in the school; it should be used and/or modified by the teacher in the further learning of abstract basic Physics concepts in order to attain a more scientific understanding of the concepts and to increase the students' learning outcomes.

One of implications of pictorial analogy is that the teachers or investigators should consider many similar features with the target concept. Due to linking prior knowledge with a new scientific one is a construction of "mental model", effective use of analogy in regular classroom should be based on a wellprepared teaching material aids.

\section{IV.CONCLUSION}

The study indicates high effectiveness of the teaching by using pictorial analogy models on total students' achievement of direct current in terms of factual knowledge, the significance of students' conceptual change, students' abilities to solve problems (procedural knowledge). In addition, the results show partially and simultaneously significant emergence of its retention. The findings have some limitations due to the effect of availability of uncontrollable factors that may intervene the internal validity of the treatment regarding the students' acquisition of prerequisite mathematics knowledge, timeschedule, and interest in Physics lesson as well. To develop more scientific understanding of the concept, the use of pictorial analogies should be initiated by assimilating it with students' prior knowledge. Based on the results, it is possible to offer some recommendations related to the professional training of future teachers regarding developing the skill of using analogies.

\section{ACKNOWLEDGMENT}

We do thank M. Iqbal, S.Pd. and his class of SMAN 1 Pontianak academic year 2017/2018 for their kind and helpful cooperation in the research.

\section{REFERENCES}

[1] Walker, J. Halliday and Resnick Fundamental of Physics Extended Eight edition. New Jersey: John Wiley and Sons (Asia) Pte Ltd; 2008.

[2] Duit R, Roth WM, Komorek M, and Wilbers J. Fostering Conceptual Change by Analogies between Scylla and Charybdis. Learning and Instruction. 2001; 11(4): 283303. DOI: https://doi.org/10.1016/S09594752(00)00034-7.

[3] Ugur G, Dilber R, Senpolat Y, Duzgun B. The Effect of Analogy in Students' Understanding of Direct Current Circuit and Attitudes towards Physics Lesson. European Journal of Educational Research. 2012; 1(3): 211-223. DOI: https://doi.org/10.12973/eu-jer.1.3.211.

[4] Bilal E and Mustafa E. Investigating Students' Conceptions of Some Electricity Concepts. Latin American of Journal Physic Education. 2009; 3(2): 193-201. Available from:

https://ajpe.org/may09/01_Esra_Bilal.pdf.

[5] Fikri K, Wiyanto, and Susilo. Penerapan Pembelajaran Fisika dengan Analogi untuk Meningkatkan Hasil Belajar Siswa SMA. Unnes Physics Educaton Journal. 2012; 1(2): 1-12. Available from: https://journal.unnes.ac.id/sju/index.php/u pej/article/view/1372. 
Jurnal Penelitian Fisika dan Aplikasinya (JPFA), 2019; 9(2): 140-151

[6] Rahmawati F, Indrawati, and Dina R. Penerapan Model Teaching with Analogies (TWA) dalam Pembelajaran Fisika di Madrasah Aliyah. Jurnal Pembelajaran Fisika (JPF). 2012; 1(2): 23-27. Available from:

http://repository.unej.ac.id/handle/1234567 $\underline{89 / 480}$.

[7] Prastowo T. Strategi Pengajaran Sains dengan Analogi: Suatu Metode Alternatif Pengajaran Sains Sekolah. Jurnal Penelitian Fisika dan Aplikasinya (JPFA). 2011; 1(1): 9-12. DOI:

http://dx.doi.org/10.26740/jpfa.v1n1.p8-13.

[8] Cibik AS and Yalclm N. The Effect of Teaching the Direct Current Concept with Analogy Technique to the Attitudes of Science Education Students towards Physics. Procedia Social and Behavioral Sciences. 2011; 15: 2647-2651. DOI: https://doi.org/10.1016/j.sbspro.2011.04.1 $\underline{63}$.

[9] Wichaidit S, Dechsri P, and Chaivisuthangkura P. Using Analogy and Model to Enhance Conceptual Change in Thai Middle School Students. US-China Education Review. 2011; 8(3): 333-338. Available from:

https://files.eric.ed.gov/fulltext/ED520455. pdf.

[10] Cinyere NM and Madu BC. Effect of Analogy Teaching Approach on Students' Conceptual Change in Physics. Greener Journal of Educational Research. 2014; 4(4): 119-125. DOI:

http://dx.doi.org/10.15580/GJER.2014.4.0 $\underline{32414160}$

[11] Glynn SM. Teaching Science with Analogy: A Strategy for Teacher and Textbook Authors. Georgia: National Reading Research Center; 1994.

[12] Glynn SM. Explaining Science Concepts: A Teaching-With-Analogical Model. In: Glynn S, Yeany R and Britton B (Eds.). The Psychology of Learning Science. Hillsdale:
Lawrence Erlbaum Associate; 1991: 219240.

[13] Paatz B, Ryder J, Schwedes H, and Scott P. A Case Study Analyzing the Process of Analogy-Based Learning in A Teaching Unit About Simple Electric Circuits. International Journal of Science Education. 2004; 26(9): 1065-1081. DOI:

https://doi.org/10.1080/146818103200015 $\underline{8408}$.

[14] Nurdiani A. Penerapan Model Pembelajaran Analogi Pokok Bahasan Listrik Dinamis untuk Meningkatkan Pemahaman Siswa Kelas IX SMP Teuku Umar Kota Semarang Tahun Pelajaran 2010/2011. Undergraduate Thesis. Unpublished. Semarang: Universitas Negeri Semarang; 2011.

[15] Chiu MH and Lin JW. Promoting Fourth Grader's Conceptual Change of Their Understanding of Electric Current via Multiple Analogies. Journal of Research in Science Teaching. 2005; 42(4): 429-464. DOI: https://doi.org/10.1002/tea.20062

[16] Dilber, R. and Bahattin D. Effectiveness of Analogy on Students' Success and Elimination of Misconceptions. Latin American Journal Physics Education. 2008; 2(3): 174-183. Available from: http://www.lajpe.org/sep08/03_Refik_Dilb er.pdf.

[17] Englehardta PV and Beichner RJ. Students' Understanding of Direct Current Resistive Electrical Circuit. American Journal of Physics. 2004; 72(1): 98-115. DOI: https://doi.org/10.1119/1.1614813.

[18] Duit R and Treagust DF. Conceptual Change: A Powerful Framework for Improving Science Teaching and Learning. International Journal of Science Education. 2003; 25(6): 671-683. DOI: https://doi.org/10.1080/09500690305016.

[19] Duit R and von Rhöneck C. Learning and Understanding Key Concepts of Electricity. In A. Tiberghien, E.J. Jossem \& J. Barajos 
(Eds.) Connecting Research in Physics Education with Teacher Education. USA: ICPE Books; 1998. Available from: https://www.univie.ac.at/pluslucis/Archiv/I CPE/C2.html.

[20] Kementerian Pendidikan dan Kebudayaan. Peraturan Menteri Pendidikan dan Kebudayaan Republik Indonesia Nomor 54 Tahun 2013 tentang Standar Kompetensi Lulusan Pendidikan Dasar dan Menengah. Jakarta: Pustaka Nasional; 2013.

[21] Saphier J, Haley-Speca MA, and Gower R. Dimensions of Questioning, Action and Research for Better Teaching Skillful Teacher: Building your teaching skills (6th ed.). Acton: RBT Research for Better Teaching, Inc; 2008. Available from: https:/www.educatored.com/CourseResou rce/course/110219/1545167/MTV\%207.2 \%20Dimensions\%20of\%20Questioning.pd f.

[22] Mahayanti D. Analisis Kesalahan Siswa dalam Mengerjakan Soal-soal pada Materi Listrik Dinamis ditinjau dari Langkah Menyelesaikan Soal pada Siswa SMA. Undergraduate Thesis. Unpublished. Surakarta: Universitas Sebelas Maret; 2015.

[23] Brown DE. Refocusing core intuitions: A Concretizing Role for Analogy in Conceptual Change. Journal of Research in Science Teaching. 1993; 30(10): 1273-1280. DOI:

https://doi.org/10.1002/tea.3660301009.

[24] Venville GJ and Treagust DF. The Role of Analogies in Promoting Conceptual Change in Biology. Instructional Science. 1996; 24(4): 295-320. DOI:

https://doi.org/10.1007/BF00118053.

[25] Sugiyono. Statistik Nonparametris untuk Penelitian. Bandung: Alfabeta; 2015.

[26] Dagher ZR. Review of Studies on The Effectiveness of Instructional Analogies in Science Education. Science Education. 1995; 79(3): 295-305. DOI:

https://doi.org/10.1002/sce.3730790305.
[27] Ramos MTG. Analogies as Tools for Meaning Making in Elementary Science Education: How Do They Work in Classroom Settings? Eurasia Journal of Mathematics, Science, and Technology Education. 2011; 7(1): 29-39. DOI: https://doi.org/10.12973/ejmste/75175.

[28] Becker LA. Effect Size (ES). Valencia: Universitat De Valencia; 2000. Available from:

https://www.uv.es/ friasnav/EffectSizeBec ker.pdf.

[29] Ekici E, Ekici F and Aydin F. Preservice Science Teachers' Views on Usability of Analogies in Science Courses and Their Examples. Journal of Kirsehir Education Faculty. 2007; 8(1): 95-113. Available from: http://journaldatabase.info/articles/preservi ce science teachers views on.html.

[30] Hynd CR, McWhorter JY, Phares VL, and Suttles CW. The Role of Instructional Variables in Conceptual Change in High School Physics Topics. Journal of Research in Science Teaching. 1994; 31(9): 933-946. DOI:

https://doi.org/10.1002/tea.3660310908.

[31] Posner GJ, Strike KA, Hewson PW, and Gertzog WA. Accommodation of a Scientific Conception: Toward a Theory of Conceptual Change. Science Education. 1982; 66(2): 211-227. DOI:

https://doi.org/10.1002/sce.3730660207.

[32] Duit R. On the Role of Analogies and Metaphors in Learning Science. Science Education. 1991; 75(6): 638-649. DOI: https://doi.org/10.1002/sce.3730750606.

[33] Lawson AE. The Importance of Analogy: A Prelude to The Special Issue. Journal of Research in Science Teaching. 1993; 30(10): 1213-1228. DOI:

https://doi.org/10.1002/tea.3660301004.

[34] Erökten S and Gökharman HK. The Effect of Analogy Method on Students Achievement in The Unit "The Structure and Properties of Matter" Civril Sample. 
Jurnal Penelitian Fisika dan Aplikasinya (JPFA), 2019; 9(2): 140-151

World Applied Sciences Journal. 2013; 23(6):744-750. DOI:

https://doi.org/10.5829/idosi.wasj.2013.23. $\underline{06.589}$.
[35] Hoyt JE and Winn BA. Understanding Retention and College Student Bodies: Differences between Drop-Outs, Stop-Outs, Opt-Outs, and Transfer-Outs. NASPA Journal. 2004; 41(3): 395-417. Available from:

https://www.tandfonline.com/doi/abs/10.2 202/1949-6605.1351. 